\title{
Biological activity studies on the aqueous methanol extract of Anchusa undulata L. subsp. hybrida (Ten.) Coutinho
}

\author{
Kevser TABAN ${ }^{1}{ }^{*}$, Nuraniye ERUYGUR ${ }^{2}$, Osman ÜSTÜN ${ }^{1}$ \\ 1 Department of Pharmacognosy, Faculty of Pharmacy, Gazi University, 06330 Ankara, Turkey \\ 2 Department of Pharmacognosy, Faculty of Pharmacy, Selçuk University, 42250 Konya, Turkey \\ * Corresponding Author. E-mail: kevsertabann@gmail.com (K.T.); Tel. +90-312-2023178; ORCID No: 0000-0001-8620- \\ 6402.
}

Received: 21 November 2017 / Revised: 02 March 2018 / Accepted: 05 March 2018

ABSTRACT: The genus Anchusa L. (Boraginaceae) is represented by 15 species in the flora of Turkey. Anchusa species are used traditionally as wound healing and diuretic agent. In addition, some Anchusa species are used as demulcent, expectorant, analgesic, sedative, diaphoretic and antihypertensive purposes. Carminative, antidiabetic, hemostatic and antirheumatical usage is also recorded. The aim of this study is to determine in vitro antioxidant, anti-AChE, anti-BuChE and a-glucosidase activity of methanol extract (Methanol: water $=80: 20, \mathrm{v} / \mathrm{v}$ ) prepared from roots and aerial parts of Anchusa undulata L. subsp. hybrida (Ten.) Coutinho. Antioxidant activity was evaluated using ABTS and DPPH radical scavenging assay, total phenolic and total flavonoid content. IC 50 values for DPPH were 239.47 and $292.04 \mu \mathrm{g} / \mathrm{mL}$ and for ABTS were calculated as 41.15 and $32.3 \mu \mathrm{g} / \mathrm{ml}$. The total phenolic content of root and herbal extract were found as 130.39 and $122.94 \mathrm{mg} / \mathrm{g}$, while flavonoid content as 65.25 and $117.5 \mathrm{mg} / \mathrm{g}$. In the enzyme inhibition studies, the methanol extract showed cholinesterase and a-glucosidase enzyme inhibition activities with the increasing concentrations. The significant enzyme inhibition activities are depended on higher amount of phenolic compounds.

KEYWORDS: A. undulate ; antioxidant activity ; anticholinesterase activity ; antidiabetic.

\section{INTRODUCTION}

Anchusa L. belongs to the Boraginaceae family. There are about 50 species of the genus in the world. The genus mainly grows in temperate and subtropical areas. This genus is represented by 15 species in the flora of Turkey and some of them are endemic. Anchusa species are known as "sığır dili" in Anatolia. Several Anchusa species are used in folk medicine as analgesic, sedative, demulcent, diuretic, diaphoretic, expectorant, hypotensive purposes in many countries [1]. In addition, roots and aerial parts of the several Anchusa species are used for anti-hypertensive, carminative, anti-diabetic, anti-rheumatic, diaphoretic, diuretic, wound healing purposes in Turkish folk medicine[2]. Some Anchusa species have been chemically studied and found to contain triterpene glycosides and flavonoid [3].

The aim of the present work is to determine in vitro antioxidant, anti-AChE, anti-BuChE and aglucosidase activity of Anchusa undulata L. subsp. hybrida (Ten.) Coutinho. Antioxidant activity was evaluated using ABTS and DPPH radical scavenging assay, total phenolic and total flavonoid content. Acetylcholinesterase (AChE) and Butyrylcholinesterase (BChE) inhibition methods were used to determine anti-alzheimer activity. Anti-diabetic activity was evaluated using a-glucosidase enzyme inhibition methods.

\section{RESULTS}

\subsection{Antioxidant activity}

There have been many reports about the close relationship between oxidative stress and chronic disease pathogenesis. Therefore, natural antioxidants can be useful in treatment of chronic disease by quenching free radicals or reducing oxidation process. In order to determine the antioxidant activity of methanol extract prepared from A. undulata herbs and roots, DPPH and ABTS radical scavenging assay, total phenol and flavonoid content determination method were used. The DPPH radical scavenging activity of extract was

How to cite this article: Taban K, Eruygur N, Üstün O. Biological activity studies on the aqueous methanol extract of Anchusa undulata L. subsp. hybrida (Ten.) Coutinho. Marmara Pharm J. 2018; 22 (3): 357-364. 
compared with BHT and BHA and results were given in Figure 1. The ABTS radical scavenging activity was compared with Trolox, an analogue of Vitamin E, and the results were showed in Figure 2.

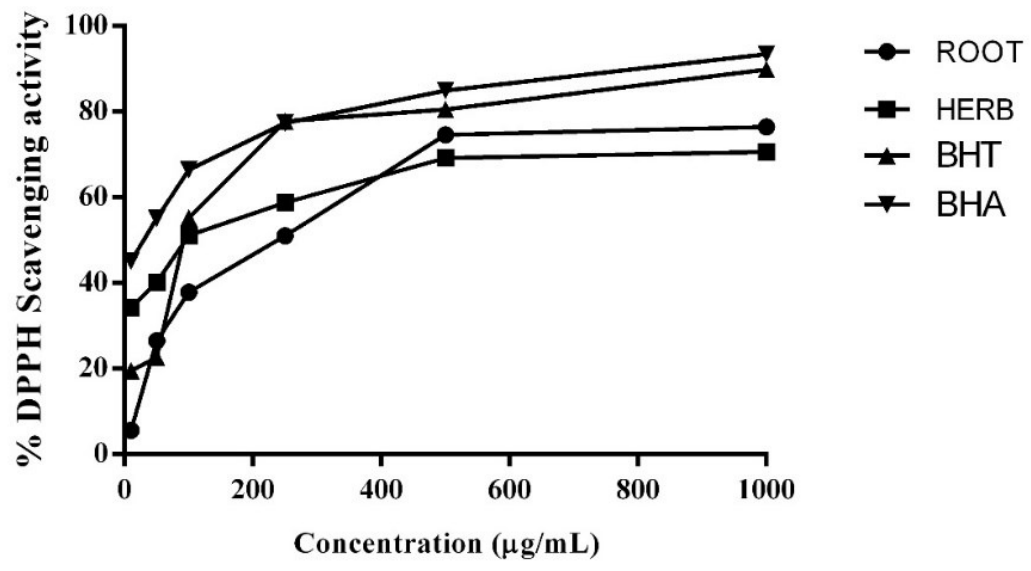

Figure 1. DPPH radical scavenging activity of methanol extract of A. undulata

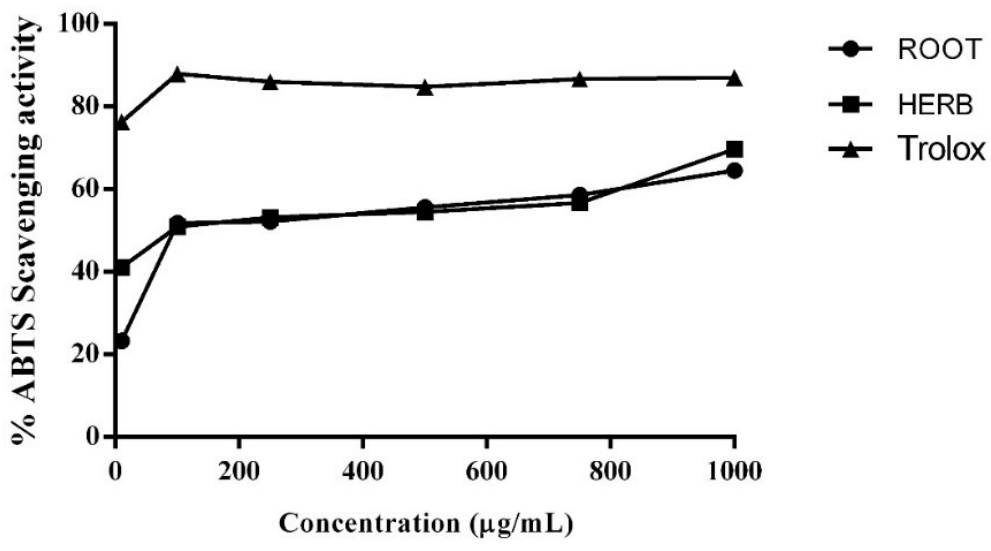

Figure 2. ABTS radical scavenging activity of methanol extract of A. undulata

Flavonoids are the important secondary metabolites and widely presented in plants. Flavonoids are structurally phenolic compounds, can act as hydrogen donor or metal chelating, and this acquired phenolic compounds as antioxidant properties [4]. The methanol extract of $A$. undulata roots have highest total phenolic contents $(130.39 \pm 0.60 \mathrm{mg} \mathrm{GAE} / \mathrm{g})$ than herbs, however total flavonoid content was just opposite that higher in herbs (117.5 $\pm 1.02 \mathrm{mg} \mathrm{QE} / \mathrm{g}$ ) than roots (Figure 3-5).

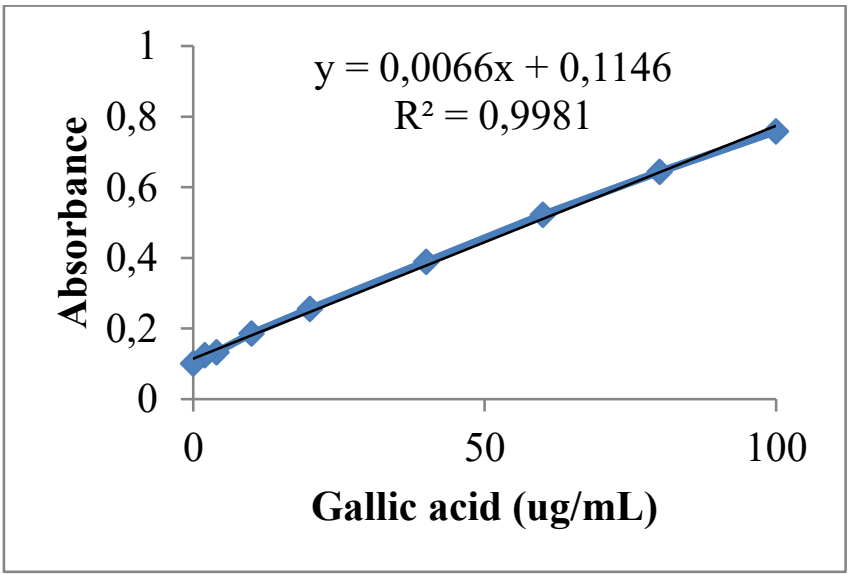

Figure 3. Calibration curve of gallic acid. 


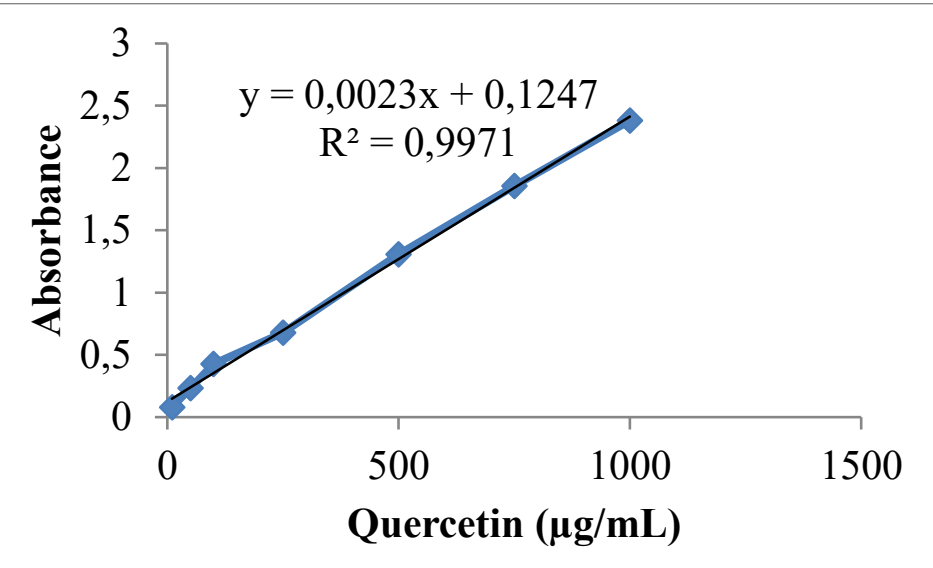

Figure 4. Calibration curve of quercetin

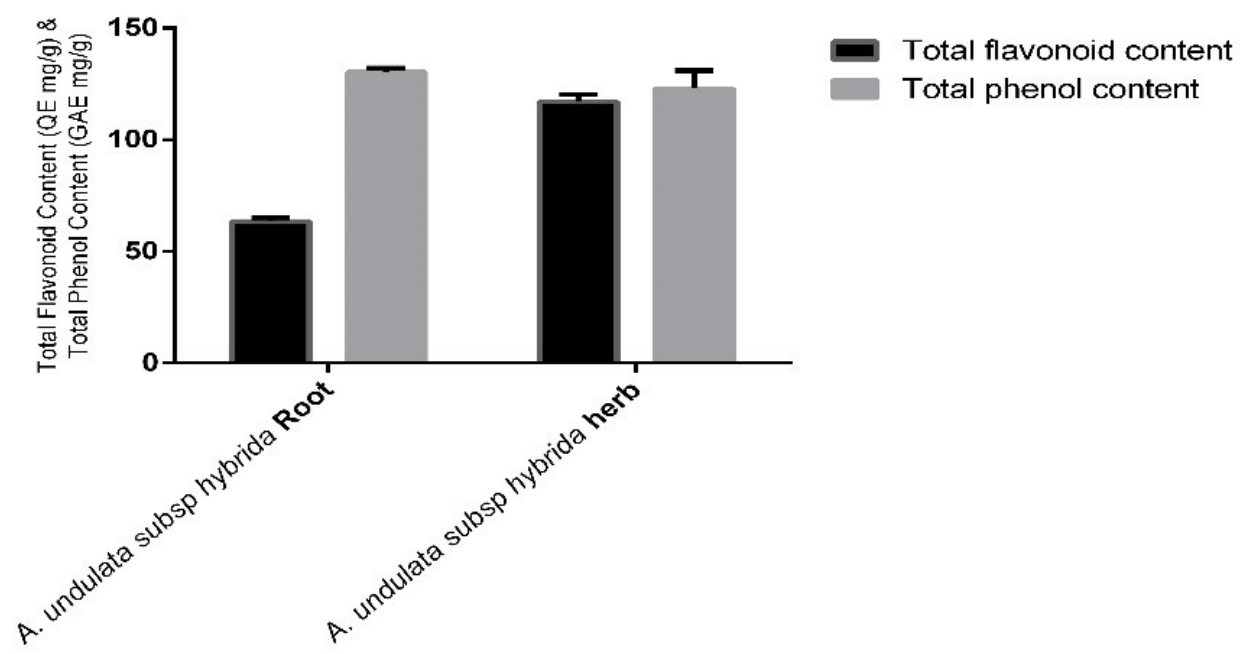

Figure 5. Total phenol and flavonoid content of methanol extract of A. undulata

\subsection{Anticholinesterase activity}

The methanol extract of $A$. undulata exhibited inhibition activity on both acetylcholinesterase and butyrylcholinesterase in dose independent manner, and the herb extracts found to be higher inhibition activity on both enzymes than root extract (Figure 6 and 7).

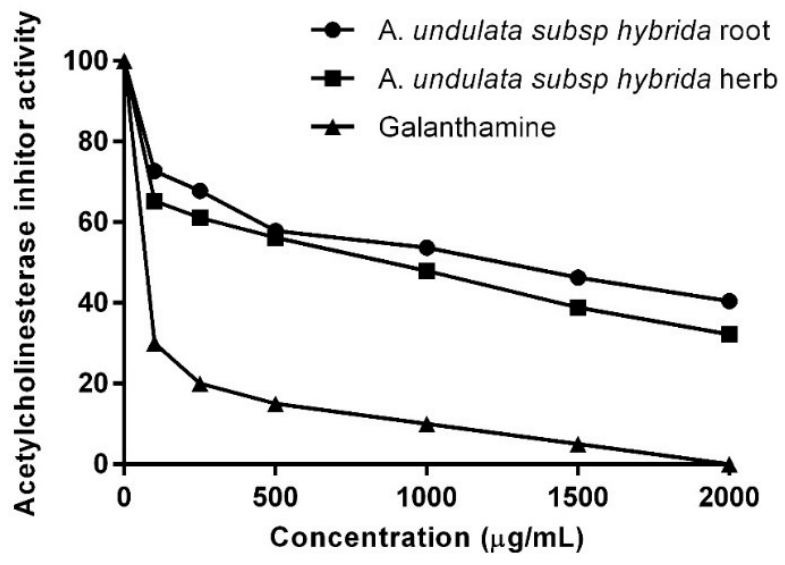

Figure 6. Acetylcholinesterase inhibition activity of methanol extract of A. undulata 


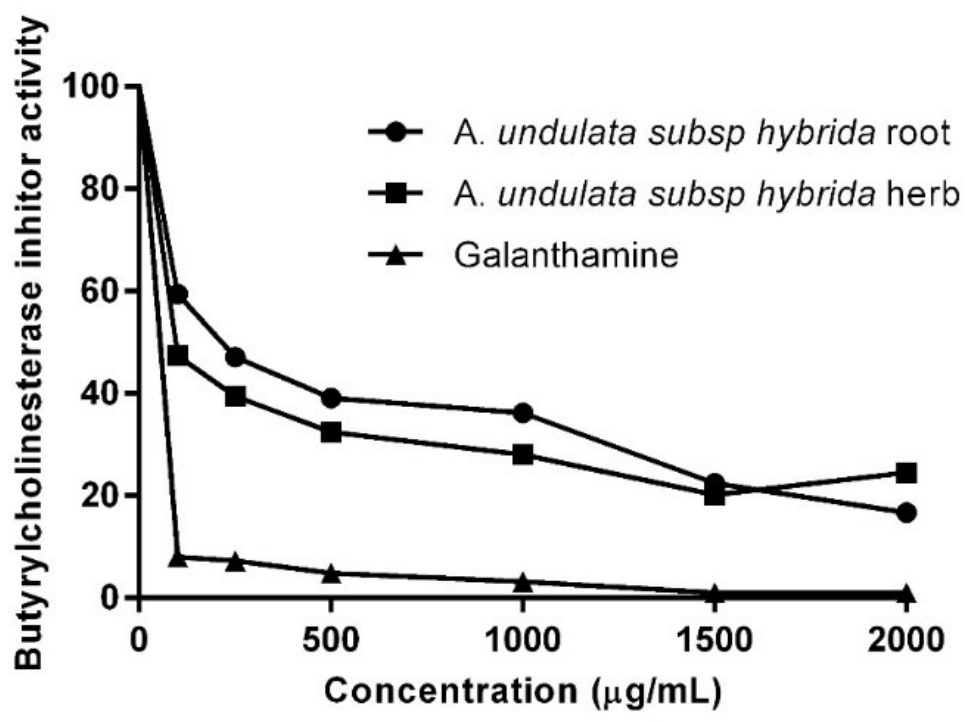

Figure 7. Butyrylcholinesterase inhibition activity of methanol extract of A. undulata.

\subsection{Antidiabetic activity}

There are mainly two carbohydrate hydrolyzing enzymes (a-amylase and a-glucosidase) are responsible for postprandial hyperglycemia. a-amylase begins the process of carbohydrate digestion by hydrolysis of 1, 4-glycosidic linkages of polysaccharides (starch, glycogen) to disaccharides a-glucosidase catalyzes the disaccharides to monosaccharides, which leads to postprandial hyperglycemia [5]. Therefore, aamylase and a-glucosidase inhibitors are considered as one of the effective measures for regulating type II diabetes by controlling glucose uptake [6]. It has been well acknowledged that plant-derived extracts and phytochemicals are potential alternatives to synthetic inhibitors against a -glucosidase [7]. The inhibitory activities of methanol extract of $A$. undulata roots and herbs were determined at different concentration $(10,100$, 250, 500, 1000, and $2000 \mathrm{mg} / \mathrm{ml}$ ) against a -glucosidase and a-amylase (Figure 8, 9).

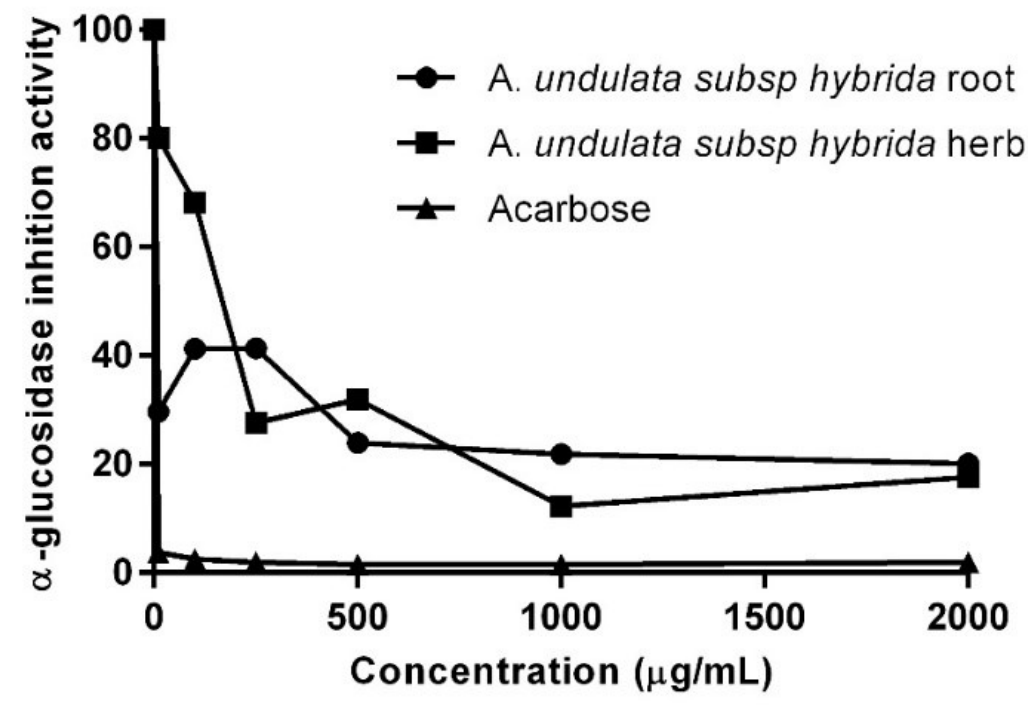

Figure 8. $\alpha$-Glucosidase inhibition activity of methanol extract of A. undulata. 


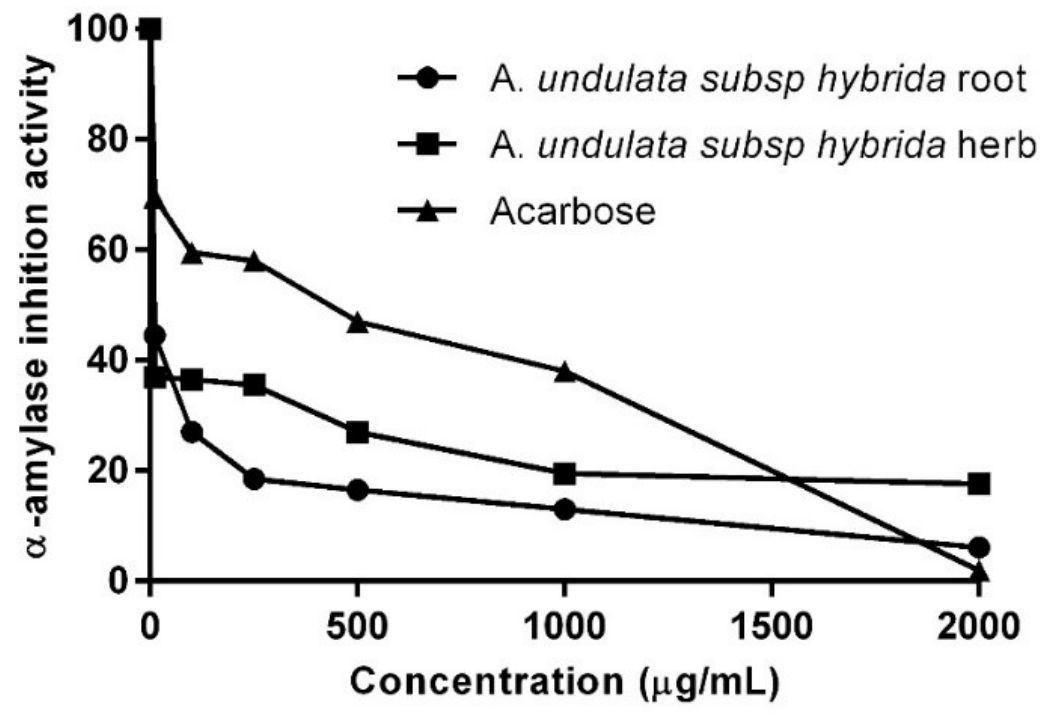

Figure 9. $\alpha$-Amylase inhibition results of methanol extract of A. undulata.

\section{DISCUSSION}

The utilization of herbal medicine as alternative to exciting medication for treatment of chronic disease such as diabetes and its complications. According to literature review on ethnobotanical area, many plants in different province in Turkey are known to have antidiabetic activity. However, there was no information available in the literature about the in-vitro antioxidant and enzyme inhibition activity on this plant. Hence the present study was aimed to evaluate antioxidant and inhibition activity on cholinesterase enzyme linked with Alzheimer disease and a-amylase and a-glucosidase which are associated with diabetes mellitus, methanol extract from A. undulata herbs and roots. According to obtained results, the phenolic compounds and flavonoids might have attributed to the highest antioxidant and enzyme inhibition activity.

\section{CONCLUSION}

The results obtained from present work prove that the methanol extract of A. undulata are effective aamylase and a-glucosidase inhibitors as well as cholinesterase inhibitors. The a-amylase and a-glucosidase inhibitors features may be helpful to reduce the postprandial glucose levels. Also this plant might be side ingredients in formulations treatment for Alzheimer disease. However, further studies on identification and characterization of active principles presented in this plant are need for developing a new Antidiabetic and anticholinesterase agents from herbal resources.

\section{MATERIALS AND METHODS}

\subsection{Chemicals}

2,2'-Diphenyl-1-picryl-hydrazyl (DPPH), 2,2-azinobis (3-ethyl benzothiazoline-6-sulfonic acid) diammonium salt (ABTS), butylated hydroxy anisole (BHA), a-glucosidase, acetylthiocholine iodide, acetylcholinesterase and butyrylcholinesterase enzymes were purchased from Sigma Chemicals Co (St. Louis, MO, USA). All of the other chemicals used in this study were of analytical grade.

\subsection{Plant materials}

Plant material was collected in June 2016 from Afyonkarahisar, Turkey and the location is given below. The plant material was identified by Dr. M. Ufuk Özbek. Voucher specimen has been deposited at the Herbarium of the Faculty of Pharmacy, Gazi University (GUEF), Turkey. Anchusa undulata subsp. hybrida: Between Afyonkarahisar and Şuhut, 38 39'04.1"N 30³5'51.8"E, 1075 m. 


\subsection{Preparation of the extract}

The roots and aerial parts of the plant were dried at the room temperature. The dried plant materials were grounded to powder using a laboratory mill and extracted with methanol:water $=80: 20, \mathrm{v} / \mathrm{v}$ for $72 \mathrm{~h}$. The extracts were filtered and solvent was removed by rotary evaporation. This extraction process was repeated with the residue for three times. Extracts were stored at $+4{ }^{\circ} \mathrm{C}$ until use.

\subsection{Antioxidant activity}

\subsubsection{Determination of total phenolic contents}

The total content of phenolic was measured as gallic acid equivalent according to the procedure [8]. 0.5 $\mathrm{ml}$ of test solution in concentration of $2 \mathrm{mg} / \mathrm{ml}$ was added with $2.5 \mathrm{ml}$ of $0.1 \mathrm{~N}$ Folin-Ciocalteu reagent and 2.5 $\mathrm{ml}$ of sodium carbonate solution (7.5\%). After vortexing, the tubes stand for $2 \mathrm{~h}$ in the dark and the absorbance was measured at $730 \mathrm{~nm}$ with UV-vis spectrophotometer (Shimadzu, UV-VIS 1800, Japan). Total phenolic content of the extract was expressed as mg gallic acid equivalents (GAE)/g dry weight basis of extract.

\subsubsection{Estimation of total flavonoid content}

Total flavonoid content was measured by aluminum chloride colorimetric method according to procedure of Yang et al.[9], and results were given as $\mathrm{mg}$ of quercetin equivalents. The flavonoid contents were calculated according to following equation obtained from the standard quercetin concentration-response graph:

Absorbance $=0.0023(\mathrm{mg}$ of quercetin $)+0.247\left(\mathrm{r}^{2}=0.9971\right)$

\subsubsection{DPPH• free radical scavenging activity}

The antioxidant activity of extracts and standards (BHA and BHT) was measured using the method of Wang et al [10]. with some modifications. $100 \mu \mathrm{L}$ of test samples in various concentration was mixed with 100 $\mu \mathrm{L}$ of methanol containing DPPH. $(0.1 \mathrm{mM})$ and incubated in the dark for $30 \mathrm{~min}$ at room temperature. The absorbance was measured at 517nm with UV-vis spectrophotometer. The \% of inhibition was calculated according to the formula:

$\%$ Inhibition $=\left(\mathrm{A}_{0}-\mathrm{A}_{\mathrm{t}}\right) / \mathrm{A}_{0}{ }^{*} 100$,

Where, $\mathrm{A}_{0}$ is the absorbance of control without sample, $\mathrm{A}_{\mathrm{t}}$ is the absorbance of test solution

\subsubsection{Antioxidant activity by ABTS radical scavenging assay}

The ABTS ${ }^{\bullet+}$ radical cation decolorization assay was carried out to evaluate the radical scavenging ability of extract using the method of Re et al.[11]. The stock solution of ABTS $\bullet+$ was generated with $2.45 \mathrm{mmol} / \mathrm{L}$ potassium persulfate and $7 \mathrm{mmol} / \mathrm{L}$ ABTS. The mixture incubated in the dark at room temperature for 12-16 $\mathrm{h}$. the working solution was prepared from stock by diluting with methanol to give an absorbance of 0.70 $( \pm 0.02)$ at $734 \mathrm{~nm} .100 \mu \mathrm{L}$ of test samples was mixed with $100 \mu \mathrm{L}$ of ABTS $\bullet+$ working solution and incubated at $25^{\circ} \mathrm{C}$ for $7 \mathrm{~min}$. The absorbance value was measured at $734 \mathrm{~nm}$ with 96 -well microplate reader instead of the UV-vis spectrophotometer.

\subsection{Determination of anticholinesterase/butyrylcholinesterase inhibition activity}

Acetylcholinesterase inhibitory activity was measured using spectrophotometric method of Ellman et al. [12] with slight modification. $140 \mu \mathrm{L}$ of $0.1 \mathrm{mM}$ sodium phosphate buffer ( $\mathrm{pH} 8.0), 20 \mu \mathrm{L}$ test sample and 20 $\mu \mathrm{L} \mathrm{AChE}(0.22 \mathrm{U} / \mathrm{ml})$ or $\mathrm{BChE}(0.1 \mathrm{U} / \mathrm{mL})$ solution were mixed at 96 well-plate and incubated for $15 \mathrm{~min}$ at $25^{\circ} \mathrm{C}$, and then $10 \mu \mathrm{L}$ of $0.5 \mathrm{mmol} / \mathrm{L} 5,5^{\prime}$-dithiobis-(2-nitrobenzoic acid) (DTNB) was added. The reaction was then initiated by the addition of acetylthiocholine iodide $(0.71 \mathrm{mmol} / \mathrm{L})$ or butyrylthiocholine iodide $(0.2$ $\mathrm{mmol} / \mathrm{L})$. The hydrolysis of substrate was monitored spectrophotometrically at $412 \mathrm{~nm}$. Percentage of inhibition of $\mathrm{AChE} / \mathrm{BChE}$ enzymes was determined by comparison of reaction rates of samples relative to blank. 


\subsection{Antidiabetic activity}

\subsection{1. $\alpha$-Glucosidase inhibition activity}

The a-glucosidase enzyme inhibitory activity was measured using the method reported by Abirami[6] with slight modifications. The test samples $(50 \mu \mathrm{L})$ were mixed with $100 \mu \mathrm{L}$ of $0.1 \mathrm{~mol} / \mathrm{L}$ phosphate buffer $(\mathrm{pH}$ 6.8) and $100 \mu \mathrm{L}$ a-glucosidase solution ( $1 \mathrm{unit} / \mathrm{mL} / \mathrm{min}$ ) and incubated at $25^{\circ} \mathrm{C}$ for $5 \mathrm{~min}$. After the preincubation, $100 \mu \mathrm{L} p$-nitrophenyl- $\alpha$-D-glucopyranoside $(5 \mathrm{mmol} / \mathrm{L})$ solution was added and the reaction mixture was incubated at $25^{\circ} \mathrm{C}$ for $10 \mathrm{~min}$. After the incubation, the absorbance was measured at $405 \mathrm{~nm}$ and a-glucosidase inhibition (\%) was calculated.

\subsection{2. $\alpha$-Amylase inhibition activity}

The $\alpha$-amylase enzyme inhibitory activity was measured using the method reported by Ademiluyi A. et al. [13] with slight modifications. Substrate was prepared by boiling $0.5 \mathrm{~g}$ potato starch in $100 \mathrm{~mL}$ phosphate buffer ( $\mathrm{pH}$ 6.8) for $5 \mathrm{~min}$, then cooling to room temperature. The $20 \mu \mathrm{L}$ samples in varying concentration, 50 $\mu \mathrm{L}$ of $0.1 \mathrm{M}$ phosphate buffer $(\mathrm{pH} 6.8)$ and $10 \mu \mathrm{L} \alpha$-amylase solution $(2 \mathrm{U} / \mathrm{mL})$ was added in 96 -well plate and the mixture was incubated at $37^{\circ} \mathrm{C}$ for $15 \mathrm{~min}$. After preincubation, $20 \mu \mathrm{L}$ of starch solution was added. Then to this mixture, $100 \mu \mathrm{L}$ of DNS color regent was added and left for $10 \mathrm{~min}$ in boiled water bath. The absorbance was measured at $540 \mathrm{~nm}$ by a microplate reader. Acarbose was used as positive control.

Author contributions: Concept - K.T., N.E.; Design - K.T., N.E.; Supervision - O.Ü.; Resource - K.T.; Materials - K.T., N.E.; Data Collection and/or Processing - N.E.; Analysis and/or Interpretation - K.T., N.E.; Literature Search - K.T., N.E., O.Ü.; Writing - K.T., N.E.; Critical Reviews - İ K.T., N.E., O.Ü.

Conflict of interest statement: The authors declared no conflict of interest.

\section{REFERENCES}

[1] Koz O, Pizza C, Kırmızıgül S. Triterpene and flavone glycosides from Anchusa undulata subsp. hybrida. Nat Prod Res. 2009; 23(3): 284-292.

[2] Kuruuzum-Uz A, Suleyman H, Cadirci E, Guvenalp Z, Demirezer LO. Investigation on anti-inflammatory and antiulcer activities of Anchusa azurea extracts and their major constituent rosmarinic acid. Z Naturforsch C. 2012; 67(78): 360-366.

[3] Kuruuzum-Uz A, Guvenalp Z, Kazaz C, Salih B, Demirezer LO. Four new triterpenes from Anchusa azurea var. azurea. Helv Chim Acta. 2010; 93(3): 457-465.

[4] Deveci E, Tel-Çayan G, Yıldırım H, Duru ME,. Chemical composition, antioxidant, anticholinesterase and anti-urease activities of Sideritis pisidica Boiss. \& Heldr. endemic to Turkey. Marmara Pharm J. 2017; 21(4): 898-905.

[5] Telagari M, Hullatti K. In-vitro a-amylase and a-glucosidase inhibitory activity of Adiantum caudatum Linn. and Celosia argentea Linn. extracts and fractions. Ind J Pharmacol. 2015; 47(4): 425-429.

[6] Abirami A, Nagarani G, Siddhuraju P. In vitro antioxidant, anti-diabetic, cholinesterase and tyrosinase inhibitory potential of fresh juice from Citrus hystrix and C. maxima fruits. Food Sci Hum Wellness. 2014; 3(1): 16-25.

[7] Kumarappan C, Mandal SC. a-Glucosidase inhibitory activity and in vitro antioxidant activities of alcohol-water extract (AWE) of Ichnocarpus frutescens leaves. Med Chem Res. 2008; 17(2-7): 219-233.

[8] Ainsworth EA, Gillespie KM. Estimation of total phenolic content and other oxidation substrates in plant tissues using Folin-Ciocalteu reagent. Nat Protoc. 2007; 2(4): 875-876.

[9] Yang H, Dong Y, Du H, Shi H, Peng Y, Li X. Antioxidant compounds from propolis collected in Anhui, China. Molecules. 2011; 16(4): 3444-3455.

[10] Wang H, Gao XD, Zhou GC, Cai L, Yao WB. In vitro and in vivo antioxidant activity of aqueous extract from Choerospondias axillaris fruit. Food Chem. 2008; 106(3): 888-895. 
[11] Re R, Pellegrini N, Proteggente A, Pannala A, Yang M, Rice-Evans C. Antioxidant activity applying an improved ABTS radical cation decolorization assay. Free Radic Biol Med. 1999; 26(9-10): 1231-1237.

[12] Ellman GL, Courtney KD, Andres V Jr, Feather-Stone RM. A new and rapid colorimetric determination of acetylcholinesterase activity. Biochem Pharmacol. 1961; 7(2): 88-95.

[13] Ademiluyi AO, Oboh G. Soybean phenolic-rich extracts inhibit key-enzymes linked to type 2 diabetes (a-amylase and a-glucosidase) and hypertension (angiotensin I converting enzyme) in vitro. Exp Toxicol Pathol. 2013; 65(3): 305309.

This is an open access article which is publicly available on our journal's website under Institutional Repository at http://dspace.marmara.edu.tr. 